\title{
The manner and form theory of parliamentary sovereignty: a Nelson's eye view of the UK constitution?
}

Article

Accepted Version

Lakin, S. (2018) The manner and form theory of parliamentary sovereignty: a Nelson's eye view of the UK constitution? Oxford Journal of Legal Studies, 38 (1). pp. 168-189. ISSN 0143-6503 doi: https://doi.org/10.1093/ojls/gqy003 Available at https://centaur.reading.ac.uk/74939/

It is advisable to refer to the publisher's version if you intend to cite from the work. See Guidance on citing.

To link to this article DOI: http://dx.doi.org/10.1093/ojls/gqy003

Publisher: Oxford University Press

All outputs in CentAUR are protected by Intellectual Property Rights law, including copyright law. Copyright and IPR is retained by the creators or other copyright holders. Terms and conditions for use of this material are defined in the End User Agreement.

www.reading.ac.uk/centaur 
Central Archive at the University of Reading

Reading's research outputs online 
The Manner and Form Theory of Parliamentary Sovereignty: A Nelson's Eye View of the UK Constitution? ${ }^{1}$

\title{
Stuart Lakin, University of Reading S.J.Lakin@Reading.ac.uk
}

\begin{abstract}
This review article examines Michael Gordon's manner and form understanding of the UK constitution. It begins by assessing his proposed 'positivist and political' method of constitutional analysis. This method, I argue, unfairly loads the dice in favour of his theory of parliamentary sovereignty. I recommend instead the anti-positivist, interpretative method as a neutral way of assessing the manner and form theory against rival theories. As an interpretation of the constitution, I argue that Gordon's account of absolute unlimited legislative authority, underpinned by the ideals of majoritarian democracy and political constitutionalism, is unconvincing. To begin with, its emphasis on reform of legislative procedures makes a peripheral, occasional, feature of the UK constitution central. More problematically, it gives an implausible model of legal and judicial practice in the UK.
\end{abstract}

Keywords: Parliamentary sovereignty, democracy, political constitutionalism, ethical positivism, common law constitutionalism, interpretivism

\footnotetext{
1 A review of Michael Gordon, Parliamentary Sovereignty in the UK Constitution: Process, Politics and Democracy (Hart Publishing 2015).
} 


\section{Introduction}

In Parliamentary Sovereignty in the UK Constitution: Process, Politics and Democracy (hereafter Sovereignty), Michael Gordon defends a manner and form theory of parliamentary sovereignty. According to this theory, Parliament possesses legally unlimited legislative authority: it can pass laws with any content it chooses, and it can change its legislative procedures in any way it chooses. Seasoned constitutional lawyers will be familiar with the Dicey-Jennings-Wade-Heuston debate about whether a sovereign Parliament has the legal power to change its own procedures. ${ }^{2}$ According to the Diceyan orthodoxy, it does not (the 'old' view), since this would amount to one parliament binding its successors; ${ }^{3}$ according to Jennings and others, it does, since this reflects the true scope of legislative authority (the 'new' view). ${ }^{4}$ In his conclusions, Gordon sides with Jennings over Dicey, but he laments the 'arid' character of that earlier exchange.5 Where Dicey and Jennings were, he says, concerned only with the logical entailments of legislative sovereignty, Gordon sets out to advance a normative justification for the manner and form

2 For a helpful overview, see AW Bradley, 'The Sovereignty of Parliament - Form or Substance?' in Jeffrey Jowell and Dawn Oliver (eds), The Changing Constitution, 7th edn (OUP 2011).

3 See AV Dicey, Introduction to the Study of the Law of the Constitution, 8th edn (Macmillan 1915). WI Jennings, The Law and the Constitution, 1st edn (University of London Press 1933).

${ }^{4}$ Gordon himself rejects the 'old' versus 'new' view framework for debate. See Sovereignty (n 1) 287.

5 ibid 15. 
theory. His arguments are rooted in democratic theory and political constitutionalism, hence the references in the sub-title of his book to process, politics and democracy.

Sovereignty is an important and impressive contribution to UK constitutional scholarship. Gordon's defence of the manner and form theory is imaginative, erudite and, I sense, driven by deeply held democratic convictions. Whether or not he persuades readers that this theory gives the best account of the contemporary UK constitution, he offers a host of valuable insights about the potential for radical reform of legislative procedures, and even of parliament itself, in the name of democracy. ${ }^{6}$ Without wishing to detract from these points, this review article will raise two critical questions about his book.

First, I shall ask whether its method is sound. A recurring theme through the chapters is the need to separate descriptive arguments about the content of the law and constitution, from normative arguments about whether that content is morally acceptable. According to Gordon, legal interpretivists mistakenly conflate legal and moral argument such that the law and constitution is whatever a given interpreter finds to be morally attractive. I shall argue that this view misrepresents or misunderstands the interpretative method. His own 'positivist and political' method, on the other hand, is question-begging and rather convoluted. Arguments about the content of the law and the constitution, I shall argue, can neither be wholly empirical as he maintains, nor wholly moral - the view he incorrectly attributes to interpretivists. Such arguments must instead involve a subtle interaction between empirical and moral facts. If this is correct, then the task of defending a manner and form reading of the UK constitution will be far more arduous than Gordon's own constitutional method would suggest.

6 Sovereignty (n 1), especially ch 8. 
My second question is how well Gordon's manner and form theory fares as an interpretation of UK constitutional practice compared to the theories he criticizes. I shall argue that his majoritarian democratic-political constitutionalist defence of parliamentary sovereignty gives a distorted and partial account of contemporary UK constitutional practice. In its emphasis on parliament's power to change its own procedures, it accentuates a part of the constitution that has little day to day significance; conversely, in its very thin account of the role of judges and adjudication, and its dismissal of common law rights and the (substantive) rule of law, it underplays parts of the constitution that dominate the modern constitutional landscape.

This review begins, in part 2, with a summary of the argument of Sovereignty. Parts 3 and 4 address the two criticisms outlined above.

2. The Argument of Parliamentary Sovereignty in the UK Constitution: Process, Politics and Democracy

Gordon's overarching aim in Sovereignty, he says, is to show that the manner and form theory of parliamentary sovereignty (hereafter 'the manner and form theory') gives the best account of contemporary constitutional practice in the UK. More particularly, he wants to show that the manner and form theory gives a better account of the contemporary constitution than one based on Dicey's doctrine of parliamentary sovereignty, or one based on common law constitutionalism (CLC). What are his yardsticks for determining whether one theory of the constitution is the correct one, or better than others? First, he looks to the 
weight of empirical evidence in its favour. Following Dicey, he thinks that descriptive analysis of "whether limits to parliamentary sovereignty have emerged is a potent means to challenge the doctrine of parliamentary sovereignty'. ${ }^{7}$ Secondly, he looks to the normative appeal of the theory. As he puts it, 'any descriptive claim about parliamentary sovereignty must also be informed by an understanding of the normative scheme underpinning the doctrine. ${ }^{8}$

In the first chapter of Sovereignty, Gordon develops this combination of normative and descriptive analysis into what he calls the 'positivist and political perspective' on the constitution. ${ }^{9}$ His perspective is positivist in that it adopts the version of positivism known (among other names) as 'ethical' positivism. ${ }^{10}$ This version of positivism claims that there are good reasons for separating what law is from what law ought to be. He pointedly prefers this version of positivism to so-called 'descriptive' positivism, on the basis that a constitutional theorist must - as he sees it - think about more than the narrow question of which criteria of legal validity exist. ${ }^{11}$

Gordon is drawn to ethical positivism on both a retail and wholesale level. On the retail level, he thinks that people should be able to identify particular legal rules without having to make controversial moral judgements. At the same time, he wants to avoid 'granting priority to the beliefs of the judiciary, who will be called upon to resolve

\footnotetext{
${ }^{7}$ Sovereignty (n 1) 16.
}

8 ibid 17.

9 ibid 19.

${ }^{10}$ In particular, he follows Jeremy Waldron's understanding of that theory. See Jeremy Waldron, 'Normative (or Ethical) Positivism' in Jules Coleman (ed), Hart's Postscript: Essays on the Postscript to the Concept of Law (Oxford, Oxford University Press, 2001). See, further, Tom Campbell, The Legal Theory of Ethical Positivism (Ashgate 1996).

11 Sovereignty (n 1) 17. 
[disputes]'.12 On the wholesale level, he argues that the separation of law and morality allows us to think about the purpose of law as a social institution. His perspective is political, he says, in that it works from the 'immanent' political principles and values within a specific constitutional order rather than from an ideal scheme. ${ }^{13}$ By basing a theory on the actual practices of a constitutional order, he says, we avoid engaging in 'abstract and unrestrained moral or political reflection'; ${ }^{14}$ we avoid the dangers of a method, which 'views all constitutional doctrine as malleable, and, if found to be unappealing, susceptible to being interpreted away';15 and we provide an 'authentic' basis on which people can understand and criticise the constitution. ${ }^{16}$ As one progresses through Sovereignty, it becomes clear that the unnamed constitutional method under attack here is the so-called 'interpretative' method found in the work of Ronald Dworkin and Trevor Allan among others. ${ }^{17}$ In part 3 (below), I shall argue that Gordon misrepresents or misunderstands that method. Far from refuting interpretivism, I shall suggest that the methodological and substantive claims about law and the constitution in Sovereignty only make sense as one contentious application of the interpretative method.

12 ibid 18.

13 ibid 20-21. The inspiration for the 'political' part of Gordon's method is Martin Loughlin, Foundations of Public Law (OUP 2010). See further Michael Gordon, 'A Basis for Positivist and Political Public Law: Reconciling Loughlin's Public Law with (Normative) Legal Positivism' (2016) 7 Jurisprudence 449.

14 Sovereignty (n 1) 20.

15 ibid 21.

16 ibid 21.

17 See, Ronald Dworkin, Law's Empire (Fontana 1986) ch 2 and passim; TRS Allan, The Sovereignty of Law: Freedom Constitution and Common Law (OUP 2013). Gordon peppers his chapters with criticisms of the interpretative method. See, for instance, Sovereignty (n 1) 17-18, $137-38,149-50,286-87$. 
One of the virtues of the positivist and political perspective, Gordon tells us, is that it successfully reconciles positivist with anti-positivist approaches to constitutional analysis. ${ }^{18}$ On the one hand, he thinks he can say with Dicey and descriptive positivists that the doctrine of parliamentary sovereignty is an empirically ascertainable fact about the constitution, rather than a doctrine whose existence depends on the strength of its justification. This means, he readily concedes, that 'the absence of a compelling normative justification could not be taken, in itself, to undermine the legal authority of this fundamental constitutional norm' ${ }^{19}$ On the other hand, he claims to be able to reach out to anti-positivists by insisting that the factual existence of parliamentary sovereignty is not the whole of the story: normative positivism, he emphasises, allows deeper enquiry about underpinnings of public law without 'reducing the validity of constitutional rules to a function of their attractiveness'.20 This normative dimension to Gordon's constitutional method, he says, also serves to distinguish his defence of the manner and form theory from that of Sir Ivor Jennings. Where Jennings engaged in debates of 'logical and legal authority rather than principle', ${ }^{21}$ Gordon seeks to 'reinvigorate the political foundations of the constitution'. 22

In line with the positivist part of his method, Gordon stresses the need to examine the 'function and virtue' of parliamentary sovereignty in tandem with, but separately from, empirical argument about its existence. By insulating the question of sovereignty's existence

\footnotetext{
18 Sovereignty (n 1) 17.

19 ibid 21.

20 ibid 20.

21 ibid 62.

22 ibid 15.
} 
from evaluative considerations, he says, we ensure that 'we know what is at stake' in the event that parliamentary sovereignty is eroded ${ }^{23}$ we resist 'casual calls' for its abandonment; and we make sure that any decision to dispense with sovereignty is made transparently. ${ }^{24}$ The function of parliamentary sovereignty, he explains, is constitutionally all-encompassing. It is a 'central organising principle', standing at the apex of the constitutional hierarchy of norms, and structuring the relationship between branches of government. ${ }^{25}$ It is a constitutional 'focal point' for citizens in the absence of a written constitution', 26 'a clear hub',27 a 'basic premise from which attempts to explore the operation of the constitution...can begin'.28

The core virtue of parliamentary sovereignty, Gordon says, is that it 'ensures the constitutional primacy of (majoritarian) decision-making'.29 Parliamentary sovereignty is about 'working things out through democratic processes'. ${ }^{30}$ As Waldron puts it, 'everything [must be] up for grabs in a democracy, including the rights associated with democracy itself'; 31 hence, says Gordon, there can neither be substantive nor procedural limits on parliamentary power. ${ }^{32}$ In circumstances of disagreement about questions of rights and

23 ibid 3,55 .

24 ibid 30.

25 ibid 24-26.

26 ibid 26.

27 ibid 26.

28 ibid 27.

29 ibid 6.

30 ibid 47.

31 ibid 37. See Jeremy Waldron, Law and Disagreement (Oxford, Clarendon Press, 1999) 303.

32 Sovereignty (n 1) 289. 
justice, a political community should make decisions by majority vote through its representatives. ${ }^{33}$ It should value process rights such as the right to participate, above a 'results-driven' approach under which judicial enforceable rights are seen as pre-conditions to democratic decision-making. ${ }^{34}$ The latter approach, he says, 'disregard[s] the respect which is accorded to citizens as a result of their very engagement in a democratic process'. ${ }^{35}$

Gordon anticipates the objection that majoritarian decision-making may lead to the 'tyranny of the majority'.36 In line with Waldron, he replies, for instance, that the tyranny of a minority of judges is worse in so far as it 'tyrannically exclude[s] certain people from participation as equals' ${ }^{37}$ Equally, he rejects as a caricature the view that Parliament is an 'elective dictatorship' dominated by government. In his view, the existing and developing mechanisms of accountability and scrutiny in parliament suffice to keep government check. $^{38}$ But even if democratic procedures prove to be imperfect, he says, majoritarian democracy allows and encourages the system to improve from within. This, in turn, avoids 'complacency about the functioning of a political system, and a willingness to explore new ways in which government can be improved'. 39

33 ibid 35, 289. See Waldron (n 31) ch 1.

34 See Ronald Dworkin, Freedom's Law: The Moral Reading of the American Constitution (Oxford, Oxford University Press, 1996) ch 1.

35 Sovereignty (n 1) 38. And see Jeremy Waldron, 'A Rights Based Critique of Constitutional Rights' (1993) 13 OJLS 18, 50.

36 Sovereignty (n 1) 39.

37 ibid 40. See Jeremy Waldron, 'The Core Case Against Judicial Review' (2006) 115 Yale Law Journal 1346, 1396

38 Sovereignty (n 1) 50-53.

39 ibid 53. 
Majoritarian democracy is Gordon's justification for parliamentary sovereignty, but what is his justification for the manner and form understanding of sovereignty? The traditional view, put forward by Heuston, was that the theory guards against 'the dangers arising from an abuse of sovereignty' in so far as it allows for procedures that make it more difficult for Parliament to legislate. ${ }^{40}$ But if limiting power were the objective, says Gordon, then CLC would arguably be a better candidate. ${ }^{41}$ Equally, the requirement (say) of a supermajority would undercut the majoritarian premise that each vote is worth the same as every other. In the face of these and other difficulties, Gordon rejects the abuse of power justification for the manner and form theory, and promises a 'fresh normative justification' for the theory. ${ }^{42}$ He takes as his starting point the view found in the early work of Jennings, that 'both the Government and the House of Commons derive their authority from the people'.43 This meant, for Jennings, that there was no need for constitutional limits on parliamentary authority. Instead, 'the accountability of the government to Parliament and the electorate was of principal significance in conditioning the use of legislative power'. 44

One of the most original and creative aspects of Sovereignty is the direction in which Gordon takes Jennings' views. In Chapter 7, he offers a novel way of reconciling the manner and form theory with majoritarian democracy, using the framework of political constitutionalism. In a challenging and densely argued discussion, which can at times be

\footnotetext{
40 RFV Heuston, Essays in Constitutional Law 2nd edn (London, Stevens and Sons, 1964), 6. Sovereignty (n 1) 287-8.

${ }^{41}$ Sovereignty (n 1) 288.

42 ibid 290.

${ }^{43}$ WI Jennings, Parliament, 2nd edn (CUP 1957) 8.

44 Sovereignty (n 1) 291.
} 
difficult to follow, he argues that the political constitutionalist ideal of prioritising politics over law can work in combination with the principle of majoritarian democracy to justify the manner and form theory of parliamentary sovereignty. ${ }^{45}$ When understood in the light of democracy and political constitutionalism, Parliamentary sovereignty becomes the 'core legal principle of the political constitution'. ${ }^{46}$ It represents the 'political principle that in a democracy there should be no legal limits to the wishes of the people'. 47 '[By] clearing the field of the possibility of legal limits on law-making power, [the doctrine of parliamentary sovereignty] creates a space which politics can, and must, fill'.48 Crucially, Gordon thinks that 'clearing the field' must extend both to matters of substance and process. Legislation should always have an effect if it is the result of the democratic decision-making process. ${ }^{49}$ This is not to say that legislative power is unlimited; 'Parliament is sovereign, but not omnipotent': it is that the limits should only be those that arise internally from democratic politics rather than those than are imposed externally through law and courts..$^{50}$

I have so far been discussing the normative part of Gordon's argument in Sovereignty (the 'positivist' side of the positivist and political perspective). What about the other side of his argument, his empirical (or 'political') defence of the manner and form theory? Gordon argues that three features of UK contemporary constitutional practice reveal, cumulatively,

\footnotetext{
45 ibid 299.

46 KD Ewing, 'The Resilience of the Political Constitution' (2013) 14 German LJ 2111, 2118.

47 ibid.

48 Sovereignty (n 1) 298, 284.

49 ibid 302.

50 ibid 5.
} 
that the manner and form theory is the 'new orthodoxy' in the constitution. ${ }^{51}$ First, the UK's membership of the EU. Second, the Parliament Acts and the decision in Jackson. ${ }^{52}$ Third, the referendum locks of the European Union Act 2011. Alongside these positive pieces of evidence, he adduces negative evidence to show how various challenges to the manner and form theory fail. These are the 'non-critical' challenges posed by devolution legislation, the Human Rights Act 1998 (HRA) and CLC. These challenges are non-critical because, he says, in the case of the devolution Acts and the HRA, the only limits on parliamentary sovereignty are political;53 and, in the case of CLC, because the theory is an 'unsustainable interpretation of the UK constitutional arrangements'.54 Gordon is wary, however, of a 'composite' challenge based on each of these non-critical challenges. ${ }^{55}$ He worries that each of these challenges threatens a 'more expansive role for judges'; 56 and he is eager to nip in the bud the risk that a 'richer [CLC] narrative' might emerge from them..$^{57}$

Gordon's analyses of the different pieces of positive and negative evidence just described are intelligent and provocative. I shall consider just a small sample of his many detailed arguments during the course of my critiques below. His strategy is to examine each constitutional provision through the lens of (principally) four different theories: his own manner and form theory, the 'constitutional revolution' theory of Wade, 58 the 'procedure and

\section{1 ibid 7.}

${ }^{52} R$ (on the application of Jackson) v Attorney General [2005] UKHL 56, [2006] 1 AC 262.

53 Sovereignty (n 1) 113.

54 ibid 114.

55 ibid.

56 ibid.

57 ibid.

58 HWR Wade, 'The Basis of Legal Sovereignty' (1955) 13 CLJ 172 
form' theory of Goldsworthy, ${ }^{59}$ and CLC. My aim is as much to question the nature of that examination as it is to question Gordon's conclusions in favour of the manner and form theory. I shall suggest that significant problems with the former cast significant doubt on the latter.

\section{The Positivist and Political Perspective: Loading the Dice}

The first question I want to raise about Sovereignty concerns its method. The point of developing a method of constitutional analysis, we might say, is to establish a way of working out which account of the constitution - the content of its legal and constitutional rights, duties and powers - is the correct or strongest one. ${ }^{60}$ The method should allow for an appraisal of rival accounts against selected criteria without favouring any given account in advance of the appraisal. ${ }^{61}$ Put differently, the method must be substantively neutral. Its focus might be, for instance, the important features of a practice, ${ }^{62}$ the 'central case' of the practice, ${ }^{63}$ or the principles that best justify the practice. ${ }^{64}$ So, given Gordon's coverage in Sovereignty, a suitable constitutional method will allow him to establish whether his manner

\footnotetext{
59 Jeffrey Goldsworthy, Parliamentary Sovereignty: Contemporary Debates (CUP 2010).

${ }^{60}$ I do not mean to say that this is the only possible aim of constitutional and legal analysis, but I take this to be Gordon's aim in Sovereignty. See Ronald Dworkin, Justice in Robes, (Harvard UP 2006) ch 8 .
}

${ }^{61}$ For discussion, see N W Barber, The Constitutional State (OUP 2010) ch 1.

62 See Joseph Raz, Ethics in the Public Domain: Essays in the Morality of Law and Politics (Clarendon Press 1994) 209.

63 John Finnis, Natural Law and Natural Rights (Clarendon Press, 1980), ch 1. 64 Dworkin (n 17). 
and form theory of parliamentary sovereignty gives a better account of the constitution than CLC or the Diceyan theories of Wade or Goldsworthy. Both parts of Gordon's positivist and political perspective appear, at first glance, to enable such a fair comparative appraisal to take place. The political part of his method holds that the correct theory of the constitution must be one that is reflected in the 'actual', 'authentic' practices and 'immanent' doctrines of the constitution. ${ }^{65}$ The positivist part holds that, besides establishing the descriptive accuracy of an account of the constitution, we should also seek to justify and evaluate the theory as a matter of political and constitutional morality. If we view Gordon's method in this skeletal form, then we can see how any one of the rival accounts of the constitution under consideration might emerge as the correct one.

Look more closely, however, and we see that both parts of the positivist and political perspective are far from neutral between competing theories. Take the following description Gordon gives of UK constitutional practice - the 'political' part of this method:

'[Parliamentary sovereignty] shapes and organises [constitutional] practice...for such practice is, to a significant extent, a function of the recognition by constitutional actors and institutions of the sovereignty of parliament...[W]ere discussion of constitutional practice to become disengaged from the doctrine of parliamentary sovereignty, the result would be, in the short term, to produce an inauthentic account of the operation of the constitution. And in the longer term, shorn of the terminology of parliamentary sovereignty, the ordering of, and relationships between, UK constitutional actors would be susceptible to changing from their present state.'66

It is clear from this passage that Gordon has very firm ideas about what counts as 'authentic', 'actual' UK constitutional practice. In his view, actual UK constitutional practice necessarily

65 Sovereignty (n 1) 21, 30.

66 ibid 29. 
reflects absolute parliamentary sovereignty and all of the many functions that he ascribes to it. A theorist whose account of the constitution denies these functions, or which eschews the terminology of parliamentary is guilty, Gordon implies, of giving an inauthentic account of UK constitutional practice. They risk changing the 'present state' of things.

This same methodological bias reappears in the other part of his method, the normative or 'positivist' part. Gordon insists, recall, that it must be possible to identify, without recourse to controversial moral judgements, the extant doctrines and practices within the constitution. For him, this allows critical reflection on the purpose of law; it allows citizens to identify their legal rights and duties; and it means that judges are not left to make contentious moral judgments about the content of the law. ${ }^{67}$ The problem here, once again, is that these values are predisposed towards his own substantive account of the constitution. As he frankly admits, we must accept the positivist separation of law and morality because that separation preserves parliamentary sovereignty: it means that Parliament's powers are not contingent on how judges interpret statutes. ${ }^{68}$

Once we expose the constitutional biases in Gordon's positivist and political perspective, it becomes clear that this is not a method of constitutional analysis at all - at least in the sense of being a substantively neutral way of determining the correct account of the constitution. Rather, it is a preliminary statement of the constitutional theory that he defends in his book, dressed-up as a method. Where a constitutional method should facilitate disagreement about the constitution, his method forestalls disagreement - other than, perhaps, on the narrow question of what parliamentary sovereignty really means. In

\footnotetext{
67 ibid 17-21.

68 ibid 149-50.
} 
order to test Gordon's manner and form theory fairly against other theories of the constitution, we need to employ some other method. Before I offer such an alternative, it is worth pointing out some of the regrettable consequences that Gordon's positivist and political perspective has for the structure and style of argument in Sovereignty. These consequences are symptomatic of the problems I have identified above.

In terms of its structure, Gordon gives us a blinkered and unbalanced view of the UK constitution. His interest is only in those those statutes, dicta, doctrines, political practices, and so on that, as he sees it, support his manner and form theory of parliamentary sovereignty. For example, he gives minimal coverage to the HRA 1998, an Act that has spawned a rich, extensive and much-debated jurisprudence; ${ }^{69}$ yet he devotes a lengthy chapter to the EU Act 2011, a provision which has hardly caused a flicker of interest among judges since its enactment. ${ }^{70}$ In part 4 below, I shall argue that Gordon's choice of positive and negative evidence gives a distorted picture of UK constitutional practice. In terms of the tone of its arguments, Sovereignty reads as a hymn of praise to majoritarian democracy and political constitutionalism and a diatribe against judicial review, the rule of law and other associated CLC ideals. Gordon's discussions are full of impassioned language in favour of parliament and politics and against judges and law: 'I categorically reject [CLC]',71 '[CLC is]

69 Other major works on the UK constitution notably place the HRA 1998 at its core. See e.g. Alison Young, Parliamentary Sovereignty and the Human Rights Act (Hart Publishing 2009); Aileen Kavanagh, Constitutional Review under the UK Human Rights Act (CUP 2009).

70 Gordon finds it 'remarkable' that section 18 of the 2011 Act was not addressed in R (HS2 Action Alliance Ltd) $v$ Secretary of State for Transport [2014] UKSC 3, [2014] 1 WLR 324. See Sovereignty (n 1) 248. The 2011 Act admittedly figured in $R$. (on the application of Miller) $v$ Secretary of State for Exiting the European Union [2017] UKSC 5; [2017] 2 WLR 583 (SC), but only as an interpretative guide to the scope of the royal prerogative: see e.g. [111]. The court attached very little importance to section 18: see [66].

71 Sovereignty (n 1) 206. 
entirely without foundation'. ${ }^{72}$ Wherever he detects a hint of support for CLC in cases, statutes, doctrines or academic arguments, he dismisses them as being, for instance, 'illusory', ${ }^{73}$ 'mere rhetoric', ${ }^{74}$ or 'aberrations'. ${ }^{75}$ Any judge or CLC theorist reading Sovereignty had better have a thick skin.

While Gordon is entitled to have the courage of his political convictions, the approach to UK constitutional analysis just described makes for an extremely polarised and non-conciliatory style of scholarship. Rarely, if ever, does he attempt to see merit in CLC, or attempt to find some common ground with it. Indeed, I shall suggest in the next section that he parodies this theory beyond recognition. CLC scholars, he says (echoing Goldsworthy) are guilty of seeking to 'sweep the field' by explaining every aspect of the constitution in terms of law and judicial power. ${ }^{76}$ Similarly, they are guilty of 'surreptitious methodological manoeuvr[ing]' by their use of an interpretative method which, as Gordon sees it, privileges the power of courts. ${ }^{77}$ The irony in these objections seems to be lost on Gordon. For they are precisely the types of problems that can be identified in his own account of the constitution. The effect of his method and substantive arguments, as seen above, is preemptively to rule out any account of the constitution that does not accept absolute parliamentary sovereignty and a minimalist account of law and adjudication. Gordon cannot

\footnotetext{
72 ibid 206.

73 ibid 132.

74 ibid 122.

75 ibid 122.

76 ibid 131. Goldsworthy (n 59) 50.

77 Sovereignty (n 1) 149.
} 
have it both ways: if he thinks a constitutional method must be neutral between different accounts of the constitution, then he must eliminate the biases in his own method. ${ }^{78}$

There is one final observation to make about Gordon's method at this stage. It leads him, at times, into precisely the style of analysis that he himself condemns as 'arid' in the work of Dicey and Jennings. ${ }^{79}$ Having declared that parliamentary sovereignty forms an essential part of UK constitutional practice, he turns his attention to investigation of the 'true nature' of sovereignty. ${ }^{80}$ In a rather dry, legalistic discussion, he explores, for instance, whether sovereignty relates both to manner and form, 81 and whether it means that parliament must have the 'capability' or 'capacity' to enact any law. ${ }^{82} \mathrm{He}$ concludes - largely in abstraction from any consideration of cases, statutes or moral theory - that the manner and form theory gives the 'true understanding of this norm'.83 Admittedly, Gordon later claims to find empirical evidence for his preferred version of parliamentary sovereignty in selected cases and statutes, but he gives the impression that much of work in defence of his manner and form theory can be done in the philosopher's armchair. If so, then this rather detracts from his aim to reinvigorate the earlier manner and form debate.

\section{A. Replacing the Dice: The Interpretative Method}

\footnotetext{
78 I take it that Gordon does support substantive neutrality by his avowed aim to demonstrate that the manner and form theory 'provides us with by far the best explanation of contemporary constitutional practice in the UK' ibid 3. The implication here is that the practice might yield any number of different explanations besides one committed to parliamentary sovereignty.

79 ibid 15.

80 ibid 75-108.

81 ibid 93-108.

82 ibid.

83 ibid 283.
} 
I have argued above that Gordon's positivist and political perspective loads the dice in favour of his own constitutional theory. We need a method that will allow for a fair contest between his manner and form understanding of the UK constitution and rival understandings. The method I propose is the so-called 'interpretative' method. According to this method, the correct understanding of the constitution is the one that gives the strongest moral justification for the salient features of UK constitutional practice. It may seem mischievous to recommend a method that Gordon himself rejects at every opportunity in Sovereignty. But I shall try to show that his objections to interpretivism are misdirected. If we understand the interpretative method correctly, we shall see that his arguments in Sovereignty are best understood in this way. This is not the place to give a full exposition or defence of the interpretative method. ${ }^{84}$ I shall instead outline the method by way of a series of correctives both to Gordon's own method and to his (mis)understanding of the interpretative method itself.

Gordon tells us, recall, that UK constitutional practice contains specific 'immanent doctrines': principally, absolute parliamentary sovereignty and its concomitant account of law and adjudication. Anyone who rejects these specific doctrines, he implies, displays a lack of fidelity to the actual practice. That this account of the practice is the correct one, he says, is true for two reasons. First, because it reflects the 'true nature' of the concept of sovereignty; secondly, because it is supported by empirical evidence from selected statutes,

\footnotetext{
84 For a particularly clear exposition and defence of the interpretative method, see Nicos Stavropoulos, 'Legal Interpretivism', Stanford Encyclopedia of Philosophy, https:// plato.stanford.edu/entries/law-interpretivist/ (accessed 2 Jan 2018).
} 
cases, dicta and political practices. ${ }^{85}$ Dworkin points to insuperable problems with both of these types of argument. In relation to the first, it makes little sense, he says, to try to uncover the true meaning of a political concept like sovereignty. Unlike a liquid or animal, such concepts have no chemical composition or DNA that will prove one understanding to be correct and others incorrect. ${ }^{86}$

Consider the main theories of legislative authority discussed in Sovereignty. Gordon thinks that parliament possesses absolute unlimited legislative authority; Goldsworthy thinks that parliament possesses unlimited authority on matters of substance, but that its authority is severely limited on matters of legislative procedure; 87 and Allan thinks that parliament authority is limited both in relation to substance and procedure (to the extent that we can separate them) ${ }^{88}$ None of these theorists will be able to persuade the others that their understanding uncovers the true nature of parliamentary authority, where the other understandings give false understandings. Disagreements about political concepts - unlike disagreements about concepts of a natural kind - simply do not work in this way.

The second empirical strategy in Sovereignty fails for similar reasons. Gordon points to selected UK statutes, cases and dicta in support of his manner and form account of the constitution; but Goldsworthy, Wade and Allan point to other statutes, cases and dicta - or to different aspects of the same statutes, cases and dicta - in support of their accounts of the constitution. For example, where Gordon points to the express words in statutes and

\footnotetext{
${ }^{85}$ See Gordon's explanation of this division at Sovereignty (n 1) 5-7 and 283.

86 See Dworkin (n 60) 150-154.

${ }^{87}$ Goldsworthy (n 59).

88 Allan (n 17).
} 
judgments, Allan points to the moral principles that best justify legal texts. ${ }^{89}$ Such different choices of evidence, in turn, give rise to very different understandings of particular institutional decisions and doctrines.

Take the decision in Anisminic, where the House of Lords interpreted a textually unambiguous statutory ouster clause to allow for judicial review to correct an error of law..$^{90}$ In line with his choice of evidence, Gordon takes this decision to be an 'aberration' within constitutional practice. 91 In line with his choice, Allan takes the same case to be paradigmatic of the way in which common law principles inform the meaning of statutes. 92 Take instead the more recent and momentous decisions in Thoburn and HS2.93 For Gordon, the constitutionalising dicta in these judgments are merely 'thematicaly influential', but without legal authority. ${ }^{4}$ For Craig the same dicta are a powerful affirmation of CLC within the constitution. 95

Where does this take us? In the face of persistent disagreements about which which evidence gives the correct account of UK constitutional practice, Gordon cannot beg the question by insisting that his choices give the empirically correct account. As far as Allan, Goldsworthy and others are concerned, their account gives the correct, authentic account of the practice, and rival accounts are inauthentic. No matter how much evidence Gordon

\footnotetext{
${ }^{89}$ Allan (n 17) 35.

90 Anisminic Ltd v Foreign Compensation Commission [1969] 2 AC 147.

91 Sovereignty (n 1) 122.

92 Allan (n 17).

93 Thoburn v Sunderland City Council [2002] EWHC 195, [2003] QB 151; HS2 (n 70) above.

94 Sovereignty (n 1) 190 and, generally, 183-192.

95 Paul Craig, 'Constitutionalising Constitutional Law: HS2' [2014] PL 373-392.
} 
summons from different parts of the practice, other theorists will point to parts of the practice that counter that evidence. And they will insist that their understanding of particular institutional decisions is correct where other accounts are incorrect. For Dworkin, this type of dispute is a dead-end. Once again, it shows that empirical analysis is the wrong type of argument for understanding constitutional practice. ${ }^{96}$ It is for this reason, I suggest, that Gordon must either modify or abandon the 'political' part of his method. He must accept that his manner and form theory is just one candidate understanding of UK constitutional practice, competing with other understandings.

We now come to the next step in the argument. Given the impossibility of factually evaluating different accounts of the constitution, we need some non-factual way of achieving this aim. ${ }^{97}$ Interpretivists such as Dworkin and Allan contend that the right type of judgement combines descriptive and moral considerations, but is neither purely descriptive nor purely moral..$^{98}$ Every account of a legal and constitutional practice, they contend, depends on, or presupposes, a contentious political theory about the nature of law, democracy, separation of powers and other political principles. ${ }^{99}$ This political theory justifies the choice of a given theorist to treat some aspects of the practice rather than others as legally or constitutionally significant.100 Gordon's emphases on absolute parliamentary sovereignty, political accountability and minimal judicial review, on this view, are not now

96 See Dworkin (n 17) ch 2. I pursue these critiques further in Stuart Lakin, 'Debunking the Idea of Parliamentary Sovereignty: The Controlling Factor of Legality in the British Constitution' (2008) 28 OJLS 709-714.

${ }^{97}$ See Mark Greenberg, 'How Facts Make Law' in Scott Hershovitz (ed), Exploring Law's Empire (OUP 2008).

98 See Ronald Dworkin, A Matter of Principle (Clarendon Press 1986) ch 6. Allan (n 17) passim.

${ }_{99}$ Dworkin (n 17) ch 3. Allan (n 17) passim.

100 See Greenberg (n 96), Stavropoulos (n 84). 
the question-begging assertions of factual correctness criticised above: they are the upshot of his majoritarian-political constitutionalist political theory. Likewise, Allan's emphases on limited parliamentary power, common law principles and constructive judicial review are the upshot of his liberal-republican political theory. ${ }^{101}$

If the relationship between moral argument and the practice just described were the end of the story, then Gordon's recurrent objections to interpretivism would be sound. $\mathrm{He}$ would be right to say, for example, that CLC scholars will 'interpret away' any part of the practice that does not conform to their moral theory. 102 And he would be right to object that the question 'is parliament sovereign?' collapses into the question 'is it justified that parliament is sovereign?'. ${ }^{103}$ But interpretivists are very careful not to end their story here. It is not enough, they say, that an account of the practice is morally attractive or unattractive. The success or otherwise of an account of the practice must depend on whether the model of the practice generated by a theorist's moral theory gives a good account of the salient features of the practice: its institutional structures, procedures, decisions and patterns of reasoning. ${ }^{104}$ In this sense, moral theory conditions the practice, but the practice conditions moral theory. 105

There is much more that needs to be said about the interpretative method, but I shall not attempt to explain or defend it any further at this point. We shall acquire a better sense of it in the next section when we see it in action. To conclude this part of the essay, I want

\footnotetext{
101 See Allan (n 17) ch 3.

102 Sovereignty (n 1) 21.

103 ibid 18.

104 Dworkin (n 17) ch 3.
}

105 ibid. 
to offer some brief reflections on how interpretative constitutional analysis improves on the form of analysis envisaged by Gordon's positivist and political perspective.

To begin with, the interpretivist method does not pre-commit us to any particular concrete doctrines in the way that Gordon's method does. It leaves open the question of what counts as the 'authentic' UK constitutional practice. Equally, interpretivism opens the way for any number of moral theories to give the best understanding of the constitution; it does not inherently privilege a judge-centric understanding of the constitution in the way that Gordon claims.106 And it may or may not support his majoritarian democratic-political constitutionalist moral convictions. Each theorist faces the same explanatory and justificatory burden to vindicate their theory. Crucially, Gordon must work much harder to make an interpretative case for the manner and form theory than the factual case envisioned by his own method.

Secondly, the interpretative method can make for more constructive style of debate between rival constitutional theorists than we find in Sovereignty. Where Gordon seems intent on torpedoing other theories, the interpretivist method encourages a charitable and constructive attitude to rival theories. ${ }^{107}$ The personal moral convictions of a theorist must give way the moral theory reflected in the practice. No matter how much Gordon opposes rights, the (substantive) rule of law and judicial review; and no matter how much Allan and others may oppose majoritarian democracy and political constitutionalism; each theorist

\footnotetext{
106 Sovereignty (n 1) 149-50. For a sophisticated argument as to why interpretivists should not focus solely on courts, see Dimitrios Kyritsis, Shared Authority Shared Authority Courts and Legislatures in Legal Theory (Hart Publishing 2015) especially ch 4.
}

107 For example, the interpretative method may conceivably support Gordon's ethical positivist views on law and the constitution. The best interpretation of a legal system might be one in which law is only the explicit rule or utterance in legal texts and judgments. See Dworkin (n 17) ch 4. 
must allow for the possibility that their disfavoured moral theories, and the institutional arrangements recommended by those moral theories, give the best interpretation of the practice. In these respects, interpretivism bridges rival legal and political theories in a way that Gordon's own method - despite his ambitions for it - manifestly does not.

\section{Does the Manner and Form Theory Give the Best Interpretation of UK Constitutional Practice?}

We are now in a position to assess Gordon's manner and form theory against other theories of the UK constitution, but not at all in the empirical fashion he himself envisages in Sovereignty. In place of Gordon's positivist-political perspective, I shall pose the following interpretative question: does Gordon's majoritarian democratic-political constitutionalist case for unlimited legislative authority justify and fit UK constitutional practice? This question leaves Gordon's detailed arguments in favour of the manner and form theory in Sovereignty where they were, but we shall see that it dramatically alters the conditions under which those arguments may provide the best understanding of the UK constitution. I shall address Gordon's interpretation of the constitution in two parts. First, his account of parliament's power to change it own procedures. Second, his account of the role of law, courts and adjudication. 108

A. Parliament's Power to Change Its Own Procedures

\footnotetext{
108 Unless I indicate otherwise, I shall use the word 'interpretation' and 'interpretative' from now on to denote the morally loaded anti-positivist method of constitutional analysis defended above.
} 
Gordon's primary aim in Sovereignty - the mission statement of his book, we might say - is to show that Parliament has an 'expanded legislative power' to change its procedures in any way it sees fit.109 How does his interpretation of this aspect of UK constitutional practice fare against that of Wade and Goldsworthy?

Wade argued that judicial obedience to statutes depends on a common law rule. ${ }^{110}$ This rule, he argued, is the ultimate political fact upon which the whole system of legislation hangs'.111 Parliament could not logically have the power to establish, change or abolish the very rule that recognises statutes as law.112 Hence, he concluded, the manner and form theory was fallacious. ${ }^{113}$ The only way that the manner and form could change was by 'revolution'; and even then it would be for courts to decide whether such a change had occurred. ${ }^{114}$ It was argued in part 3 above that Gordon cannot defeat this view as a matter of acontexual, conceptual analysis; he must instead show that Wade's theory neither fits nor justifies UK constitutional practice. When understood in this interpretative way, Gordon's arguments are persuasive. As a matter of political morality, he argues that Wade's theory makes constitutional change almost impossible, 'entrench[ing] in the wider political culture a sense that fundamental constitutitonal reform need not be seriously considered, because it is - at least in accordance with the rules of the existing system - impossible

109 Sovereignty (n 1) 323.

110 Wade (n 58).

111 Sovereignty (n 1) 189.

$112 \operatorname{Ibid} 188$.

113 ibid 189.

114 Ibid 189. 
lawfully to effect.'115 In addition, Gordon rejects Wade's theory for being court-centric. He finds it paradoxical for courts to have such a central role in the event of an extra-legal constitutional revolution. ${ }^{116}$

These moral arguments against Wade's theory cannot, by themselves, defeat his 'revolutionary' view. It is not enough that Wade's theory may unsettle Gordon's individual moral convictions about the primary of democratic decision-making. ${ }^{117}$ As an interpreter, Gordon must further show that these moral arguments do not fit UK constitutional practice. Here again, his argument is persuasive. Wade's view that any fundamental change to the constitution is revolutionary and extra-legal, Gordon argues, is is counter-intuitive and contrary to established constitutional practice. ${ }^{118}$ The enactment of the ECA 1972, for instance, was clearly within the existing legal framework rather than an extra-legal revolution: 'the essential domestic architecture was untouched'. ${ }^{119}$ And even if one looks at episodes in constitutional history that were far more plausibly revolutionary in character, it is clear enough that Wade's court-centric view is 'far removed from the reality of revolutionary change, in which multiple constitutional and political actors will be engaged in, and influence, a complex process of reshaping or reconstituting a community's system of government'.120

\footnotetext{
115 ibid 79.

116 ibid 78-79.

117 ibid 79.

118 ibid 76-83.

119 ibid 154-5.
}

120 ibid 78. Gordon gives the example here of the Glorious Revolution of 1688. 
What about the 'procedure and form' view of Goldsworthy? Goldsworthy contends that there must be legal limits to the changes parliament can make to its own procedures. Only by narrowing the range of possible procedural changes, he argues, can we ensure that Parliament does not inadvertently limit itself in substance. The test he lays down is as follows:

'legally binding and judicially enforceable requirements as to procedure or form are consistent with parliamentary sovereignty, provided that they do not control or restrict the substantive content of legislation, or make it so difficult for Parliament to legislate that its power to do so is diminished'.121

He reserves the power for courts to adjudicate on his 'so difficult' and 'diminished' tests. ${ }^{122}$ Gordon recommends a far less restrictive test: Parliament can enact any measure, he says, provided that is does not make it 'effectively impossible' to legislate. ${ }^{123}$ He thinks that this modest limit should be policed by politics rather than judges. ${ }^{124}$ Underlying these two views of parliamentary authority are two competing theories of democracy and separation of powers. For Goldsworthy, democracy requires that the proposed measure 'enjoy[s] widespread, non-partisan support... [and is]...consistent with democratic principle'.125 This understanding of democracy, and the role he assigns to courts, perhaps recalls Dworkin's

\footnotetext{
121 Goldsworthy (n 59) 174.

${ }^{122}$ An example of where courts should disallow a procedure under these tests, he says, is a requirement for a two thirds super-majority. Such a provision 'should not be regarded as purely procedural' he argues, because '[i]n effect, they give a minority of members the power to veto legislation'. ibid 198.

${ }^{123}$ Sovereignty (n 1) 104.

124 ibid 302-322 and 105-107.

125 Goldsworthy (n 59) 140.
} 
'constitutionalist' theory. 126 For Gordon, by contrast, majoritarian democracy and political constitutionalism combine to give Parliament and politics untrammelled power.

Which of these moral theories gives the better interpretation of the practice?127 Space does not permit a thorough comparison. One possible implication of Goldsworthy's procedure and form theory is that the referendum locks contained in the EU Act 2011 Act are legally impermissible. Since these locks arguably diminish parliament's power to enact law, then, according to his Diceyan view of parliamentary sovereignty, the 2011 Act cannot be a valid act.128 If so, then this must count against Goldworthy's position. ${ }^{129}$ If a constitutional theory cannot explain a provision widely held to be valid law within a legal system, then it is likely to be the theory rather than the provision that we need to question. On the other hand, support for Goldsworthy's account can perhaps be found in Jackson. ${ }^{130}$ The very decision by the House of Lords to adjudicate on the validity of the Parliament Act 1949 and the Hunting Act 2004 arguably chimes with Goldsworthy's views on the

\footnotetext{
126 Dworkin (n 34).
}

127 I am conscious that Goldsworthy, like Gordon, may well resist this interpretative recasting of his theory, but my view is that this is the best way to understand each of their views. See further, Stuart Lakin, 'Defending and Contesting the Sovereignty of Law: The Public Lawyer as Interpretivist' (2015) 78 MLR 549-570, 563-564.

128 Sovereignty (n 1) ch 6.

129 Goldsworthy resists that conclusion by subtle adaptation of his theory. See Jeffrey Goldsworthy, 'Parliamentary Sovereignty's Premature Obituary' UK Constitutional Law Blog (3 September 2012), https://ukconstitutionallaw.org/2012/03/09/jeffrey-goldsworthy-parliamentary-sovereigntyspremature-obituary/ (accessed 2 Jan 2018). 
democratic need for judicial review of procedures; ${ }^{131}$ so too does the character of the court's reasoning in terms of the democratic limits to the use of the 1949 Act. 132

The last few paragraphs above give just a small peek into Gordon's intricate arguments about parliament's power to change its legislative power. Rather than attempt to comment any further on the details of his arguments, I want to make a broader point about the emphasis he places on manner and form considerations in Sovereignty. Whether or not he persuades us that parliament has successfully changed its legislative procedures in one or more of the ECA 1972, Parliament Acts and EU Act 2011, there is something odd, I think, about hanging an entire theory of the UK constitution on this power and this sprinkling of statutes. In the first place, few (if any) theorists today deny that parliament possesses such a power, even if they disagree about its true nature and extent. ${ }^{133}$ More troublingly, the effect of Gordon's emphasis is to move a peripheral and occasional part of UK constitutional practice to the centre ground. It implies that parliament's day-to-day legislative activity on manifold issues of substance is relatively uninteresting and uncontentious for a constitutional theorist. Gordon's final two chapters in Sovereignty - and substantial parts of his earlier chapters - are pretty much all about the manner and form power: its nature and justification, how parliament can be held politically to account for its use, and the way in which parliament could, in future, exercise it. If his book were entitled 'Constitutional Reform in the UK', this emphasis would make perfect sense. But the emphasis raises alarm bells in a book whose aim is to elucidate existing UK constitutional practice.

\footnotetext{
131 ibid [27].

132 See, for instance, the dictum of Lord Nicholls. ibid [59]. See Goldsworthy (n 59) 176-178.

133 For instance, Young argues that, even within Dicey's conception of parliamentary sovereignty, it is possible to entrench human rights. See Young (n 69) chs 2 and 3. Similarly, Goldsworthy claims to be able to accommodate the EU Act 2011 within this theory (n 129) above.
} 
As an interpreter of the constitution, Gordon must use a much broader brush. $\mathrm{He}$ must show that his majoritarian democratic-political constitutionalist theory of absolute power gives a compelling account of UK constitutional practice as a whole. In particular, he must show that his theory can make sense of the role of law, judges and adjudication: how the phenomenon of statutory interpretation and common law reasoning impacts on the full range of parliament's legislative powers; and how it impacts on his ideals of political accountability. An interpretation that fails to account adequately, or at all, for these salient features of the practice will hardly be an interpretation at all.

B. Law and Adjudication

A frustrating feature of Sovereignty is that Gordon fails to provide a positive, developed model of law and adjudication to accompany his highly developed model of political power and accountability. ${ }^{134}$ Much of the time, we have to infer his views from his criticisms of CLC and the rule of law, and his support for particular judgments and dicta. Perhaps the most promising starting point is the theory of adjudication implicit in his political and positivist method. The retail part of his ethical positivist part, recall, holds that citizens and judges should be able to identify clear rules without the need for contentious moral judgment. This also means that judges will not be called upon to decide cases according to their own moral preferences. Gordon seems to have in mind here a strict 'formalist' account of law and adjudication where law must take the form of clear, ascertainable rules. The role

134 This is a common shortcoming in political constitutionalist literature. See Paul Craig, 'Political Constitutionalism and the Judicial Role: A Response' (2011) 9 IJCL112. 
he assigns to judges, it seems, is to apply those rules mechanically, without exercising judgement or discretion.

Further evidence for this formalist view is found in Gordon's sustained critique of CLC. The first of his major objections to CLC is its imprecision: it does not allow us to 'pin down a definitive list' of rights; ${ }^{135}$ it prizes 'flexibility at the cost of uncertainty'; 136 '[c]itizens cannot know their rights'. ${ }^{137}$ These types of objections from legal certainty reappear in Gordon's criticisms of the (substantive) rule of law. The rule of law is 'too indeterminate to provide useful guidance'; it 'exacerbates the imprecision of the CLC'; it can lead to 'sudden change in law' with 'no advance notice or consultation'138 We can glean a little more about Gordon's view on law and adjudication from his second major objection to CLC, namely its undemocratic character. Democracy, he says, is a 'crucial feature in determining the role of judges'. ${ }^{139} \mathrm{CLC}$, he says, is 'fundamentally undemocratic', 140 'rights focused' and individualistic. ${ }^{141}$ Unfortunately, we do not clearly learn from Gordon what form of adjudication would satisfy democracy, and how judges should avoid a focus on individual rights.

Does Gordon's theory of law and adjudication give a good understanding of UK constitutional practice? In my view, he pitches two equally implausible theories of law and

\footnotetext{
135 Sovereignty (n 1) 143.

136 ibid 143.

137 ibid 144.

138 ibid 146-148.

139 ibid 141.

140 ibid 141.

141 ibid 143.
} 
adjudication against one other in his discussion of UK case law and statutes: either judges apply the actual explicit conditions that have been put in place by Parliament, or they indulge in unrestrained moral and political argument with little or no regard for legal texts. ${ }^{142}$ Take his account of Jackson. ${ }^{143}$ On his extremely narrow reading of the case, the law was clear, and so there was no genuine legal dispute. ${ }^{144}$ It follows that, for him, the (much-lauded) reasoning of the judges on principles of sovereignty, democracy, the rule of law, and so on, was nothing more than 'confused and contradictory rhetoric'.. ${ }^{145}$ Similarly, the Pierson 'legality' principle involves a 'subversion of the literal meaning of [statutes]...' and provides no precise guide to as to what language Parliament would need to use to abrogate fundamental rights. ${ }^{146}$ In effect, he says, judges use the principle in any way they like. ${ }^{147}$ Again and again, Gordon presents judicial decisions and doctrines in this polarised way - often using excessively dismissive language. ${ }^{148}$

The problem with Gordon's formalist account of law and adjudication is precisely the one that I identified in the 'political' part of his methodology above. He advances his formalist account as the factually correct one, and he insists that every other approach is

\footnotetext{
142 ibid, especially 201-217.

143 Jackson (n 52)

144 Sovereignty (n 1) 197.

145 ibid 203. For a laudatory account, see Jeffrey Jowell, 'Parliamentary Sovereignty Under the New Constitutional Hypothesis' [2006] PL 562.
}

146 Sovereignty (n 1) 215. Rv Secretary of State for the Home Department, ex parte Pierson [1998] AC 539.

147 Gordon nonetheless seems to support the principle on the basis that Parliament retains the power to legislate contrary to fundamental rights. Sovereignty (n 1) 217.

148 E.g: '[The] judicial reiteration of [fundamental principles] may appear to be a rather banal message...' ibid 236; 'the courts...somewhat haphazardly...' ibid 216 (my italics). 
factually incorrect. But here again he begs the question. A characteristic feature of common law legal practice is 'hard' cases - cases in which the meaning of a statute or judgment is unclear. In such cases - and perhaps in all cases - judges make different choices about how to interpret the legal texts. They draw upon different principles and policies to justify one choice over others. There can be few better examples of the diverse judicial approaches to statutory interpretation than in Jackson itself. ${ }^{149}$ Even supposing that it is ever possible to identify an 'actual' parliamentary intention, that form of interpretation routinely competes with other forms. If Gordon is successfully to defend a majoritarian-political constitutionalist vision of the constitution, he must show how judicial disagreement fits within that vision. He cannot simply wish it away, dismissing any reasoning at odds with his own formalist theory as 'mere rhetoric'. ${ }^{150}$

What about CLC? Gordon's account of this theory as 'merely normative ',151 I am afraid, is nothing more than a parody - much like his treatment of the interpretative method on which CLC scholars depend. The 'constructive' form of interpretation employed by CLC scholars, correctly understood, is a careful attempt to understand the interaction between legal texts and moral rights and principles in hard cases. ${ }^{152}$ Judges have a duty to interpret statutes and common law judgments in light of the moral scheme underlying those provisions - and underlying legal practice as a whole. In this way, the law is neither brute

\footnotetext{
${ }^{149}$ See Lakin (n 96). See further Thomas Fairclough, 'Evans $v$ Attorney General: The Underlying Normativity of Constitutional Disagreement' in Satvinder Juss and Maurice Sunkin (eds), Landmark Cases in Public Law (Hart Publishing 2017).

150 Sovereignty (n 1) 122.

151 Sovereignty (n 1) 190.

152 See the extremely rigorous defence of this CLC dynamic in Allan (n 17) especially ch 5.
} 
fact nor ideal moral theory: it is, as Kyritsis puts it, 'justice in an institutional context.'153 When understood properly, the CLC model of law and adjudication gives a highly persuasive account of UK constitutional practice. For instance, it closely captures judicial reasoning on the 'legality' principle; ${ }^{154}$ and it makes good sense of the ECA 1972 and Factortame debates. ${ }^{155}$ Whatever his moral misgivings about law and judges, Gordon must confront CLC on its merits rather than hurl insults at a straw-man version of the theory - no CLC scholar would recognise or endorse the version he attacks in Sovereignty. ${ }^{156}$ It may well be that he could develop a powerful political constitutionalist answer to the (actual) CLC account of judicial disagreement, adapting more sophisticated models of positivist adjudication in hard cases. ${ }^{157}$ Sovereignty is something of a missed opportunity in this respect.

\section{Conclusion}

153 Kyritsis (n 106) 110.

${ }^{154}$ See the cases and judgments discussed by Gordon in Sovereignty (n 1) 207-217.

155 ibid ch 4. See, especially, TRS Allan, 'Parliamentary Sovereignty: Law, Politics and Revolution' (1997) 113 LQR 443-452. See further George Letsas, 'Harmonic Law: The Case Against Pluralism' in Julie Dickson and Pavlos Eleftheriadis (eds), Philosophical Foundations of European Union Law (OUP 2012).

${ }^{156}$ For a sample of Gordon's invective against CLC, see the text to footnotes $72-75$ above. His tone sometimes verges on sarcasm e.g. 'the values of [CLC] will necessarily be imprecise to ensure that the theory's precious amenability is maintained' Sovereignty (n 1) 143, and "...parliamentary supremacy, whatever that might mean...' ibid 208.

157 I explore this possibility in Lakin (n 127). 
There are many intriguing features of Sovereignty that I have not been able to discuss in this review. Readers will find much interest, for instance, in his analysis of the competing perspectives of Dicey and Jennings on law and politics, ${ }^{158}$ and in the way that Gordon traces the evolution of ideas in Jenning's work. ${ }^{159}$ My focus has instead largely been a methodological one. I have tried to highlight some problems with the approach Gordon takes to constitutional analysis - his positivist and political perspective. This approach, I have argued, does not allow for a fair comparison between competing accounts of the constitution; it loads the dice in favour of Gordon's substantive theory. I have instead examined his majoritarian democratic-political constitutionalist theory of absolute unlimited legislative authority as a morally contentious interpretation of UK constitutional practice. When assessed in this way, I think his account falls short. It has too much to say about the power of parliament to change its own legislative procedures; and it has too little to say about the role of law and adjudication within the constitution.

158 Sovereignty (n 1) 58-74.

$159 \mathrm{ibid}$ and 89-90, 286-290. 
